\title{
Standard of Care and New Operative Techniques for Small Renal Tumors: a Meta-analysis with a Special Focus on Cryoablation
}

\author{
Thomas G. PODER \\ UÉTMIS - CHU of Sherbrooke - CANADA \\ GREDI - University of Sherbrooke - CANADA \\ Unité d'Évaluation des Technologies et des Modes d'Intervention en Santé (UÉTMIS) \\ Centre Hospitalier Universitaire de Sherbrooke (CHUS) \\ Hôpital Fleurimont, 3001, 12e avenue Nord, Sherbrooke J1H 5N4 \\ Québec, Canada \\ E-mail: tpoder.chus@ssss.gouv.qc.ca
}

Jie HE

Université de Sherbrooke - Département d'économique \& GREDI - CANADA

2500 Bd. Université, Sherbrooke J1K 2R1, Québec, Canada

E-mail: jie.he@usherbrooke.ca

\author{
Renald LEMIEUX \\ UÉTMIS - CHU of Sherbrooke - CANADA
}

Hôpital Fleurimont, 3001, 12e avenue Nord, Sherbrooke J1H 5N4, Québec, Canada

E-mail: rlemieux.chus@ssss.gouv.qc.ca

\begin{abstract}
Introduction: the aim of this article is to realize a meta-analysis of published data evaluating open nephrectomy, laparoscopic nephrectomy and cryoablation for small renal masses to define the current data, and to adjust oncological results for patients and follow-up heterogeneity by performing econometric estimations.

Materials and methods: a systematic literature review using the STROBE checklist was performed for clinically localized sporadic renal masses from the beginning of January 1996 until October 31, 2008. The main variables evaluated were patients' age and sex, tumor size, ASA score, duration of follow-up, available clinical outcomes, pathological data, and oncological outcomes.

Results: 152 studies representing 19994 patients were analyzed. The authors found a significant lower operation time for percutaneous cryoablation, and a lower hospital stay and blood losses for all types of cryoablation (i.e. open, laparoscopic and percutaneous). No significant difference is found between cryoablation and resection methods as regard to complication rates. When adjusting oncological results for patients and follow-up heterogeneity, higher recurrence rates at five years are found for cryoablation, on the contrary, no difference is found for specific-cancer survival rates at five years.

Conclusions: cryoablation is a safe and less invasive procedure than resection methods. However, its long term efficacy has not yet been established and a more stringent selection of patients is needed to reduce recurrence rates.
\end{abstract}

Keywords: Cryoablation, Nephrectomy, Laparoscopy, Small renal tumors, Meta-analysis

\section{Introduction}

Worldwide, more than 100000 deaths occur from renal cell carcinoma (RCC) each year. RCC accounts for $2-3 \%$ of all adult malignancies and is the most lethal of the urologic cancers (Parkin et al., 2002; Jemal et al., 2003). Unlike many other cancers, the incidence of kidney cancer is steadily increasing at a rate of about $2.5 \%$ 
per year across population groups (Pantuck et al. 2001; Hankey et al., 1999; Chow et al., 1999). Recent techniques of abdominal imaging have revealed a new population of renal tumors whose size is less than $4 \mathrm{~cm}$. This population currently represents $60 \%$ to $70 \%$ of incidentally detected renal tumors (Chow et al., 1999; Russo, 2000). Over $30 \%$ of these small renal tumors are benign or indolent, and many are growing slowly (Frank et al., 2003; Rukstalis et al., 2006) at about $0.35 \mathrm{~cm}$ per year (Bosniak et al., 1996).

Although small lesions may be at low risk for dissemination and metastases, they have the ability to metastasize, that's why ablative treatment is commonly performed for small renal masses with imaging criteria suspicious for malignancy. Besides, this ablative treatment is all the more necessary insofar as current techniques of medical imaging are unable to clearly distinguish between benign and malignant tumors, and because results of biopsies are only 70-80\% reliable (Dech et al., 2003; Israel and Bosniak, 2005). Given this uncertainty and the risk of morbidity associated with excision of renal tumors through open surgery, urology surgeons are therefore increasingly favoring techniques that are less invasive, such as laparoscopy and percutaneous ablation of renal tumors by radiofrequency or cryotherapy. The latter two techniques are not yet part of the standard list of treatments available for patients as their therapeutic efficacy is not statistically supported by a sufficiently large number of medical studies over long periods. For this reason, many physicians consider these new promising techniques as experimental and are hesitant to use them. These two techniques can also be used in open or laparoscopic methods and their use is generally limited to: renal tumors less than $4 \mathrm{~cm}$, exophytic or polar, non-cystic, away from the elements of the hilum (vessels and pelvis) and the digestive structures, and in a single kidney or a transplanted kidney.

The aim of this article is to perform a comparison of four different operative techniques for small renal tumors: open nephrectomy, laparoscopic nephrectomy, cryoablation surgery, and percutaneous cryoablation. In doing so, a systematic literature review is provided by comparing the results of the cryoablation technique to standard procedures (i.e. open and laparoscopic nephrectomy) for small renal tumors. Subsequently, from a subset of observed values, missing data is randomly simulated because studies often lack some data. This data simulation allows for a more precise analysis of oncological results. Finally, econometric estimations are performed to adjust oncological results for patients and follow-up heterogeneity.

\section{Systematic literature review}

\subsection{Methodology}

Search engines used for this systematic review are Embase, CINALH, AMED, OVID HealthSTAR, OVID Medline, Mantis, Pubmed, ScienceDirect, British Medical Journal, Cochrane Database, and the Center for Research and Dissemination. The websites of the Quebec "Agence d'évaluation des technologies et des modes d'intervention en santé", the National Institute for Health Research (NIHR) Health Technology Assessment Programme, the International Network of Agencies for Health Technology Assessment, the InfoBank of the Canadian Medical Association, the National Guideline Clearinghouse, and the "Répertoire des recommandations de bonne pratique \& des conférences de consensus francophones" were also consulted.

The reference period used for the search for articles was from the beginning of January 1996 until October 31, 2008. The languages used for this research are mainly English and French. The key words used in the different search engines are: cryoablation, cryotherapy, cryosurgery, cryobiology, laparoscopic, renal, kidney, and tumor.

Studies found duplicate in several search engines were considered as a unique study (i.e. they were not accounted several times). Results provided by the search engines and web sites consulted allowed listing more than 2000 articles from journals with a peer review committee, and four guides of good clinical practice. Among these articles, many did not correspond to the object of this research. Thus, all articles that did not address renal tumors in humans were excluded. To determine which articles were to be excluded, summaries of each of them were read by two reviewers and their appropriateness with the subject of this research was discussed according to our inclusion criteria (i.e. renal tumor, cryoablation, laparoscopic and open surgery, statistical analysis). The number of articles resulting from this initial selection was thus reduced to 325 . After reading these 325 studies, with the exclusion criteria adopted (i.e. research on animals, five or less patients, studies with subgroups of patients mostly from other studies, studies giving average results of several techniques of ablation or surgery without the possibility of making a distinction, metastatic kidney cancer), only 154 studies constituting 227 groups of patients were finally selected for this analysis. Within these 154 studies, only two were randomized and 25 designed as prospective; however, none of them were on cryoablation. Moreover, it is important to note that in almost one study in four (34/154) no information on the type of methodology is provided. Given these factors, it was difficult to exclude studies in accordance with their level of evidence without losing too many details. Moreover, often, there is no significant difference in the quality of randomized trials methodologically 
well designed and observational studies methodologically well designed (Benson and Hartz, 2000; Concato et al., 2000; Pocock and Elbourne, 2000).Consequently, it was decided to exclude studies on the basis of the quality of the information provided by using the STROBE checklist (Note 1). In some cases, authors of the studies were contacted in order to get additional information about the study design and the analysis. Studies failing to meet a minimum of 15 to 22 items were excluded from this analysis, which finally allowed retaining 152 studies. All items were discussed between two reviewers. Whatever where is the information provided in the study, this information was considered suitable to complete the checklist. Discrepancies and disagreements between the two reviewers were discussed with a third reviewer who indicated if the study meets or not the item in the STROBE checklist. The decision of choosing a selection criteria that may seem weak (i.e. a minimum of 15 to 22 items) is due to the fact that not having certain information due to a limited number of words imposed in the published literature should not be a strict exclusion criteria because it does not guarantee a low level of evidence from these studies.

From the 152 studies selected for this analysis, 225 groups of patients were studied. Among these 225 groups, 73 deal with laparoscopic partial nephrectomy (LPN), 34 with laparoscopic radical nephrectomy (LRN), 38 with open partial nephrectomy (OPN), 27 with open radical nephrectomy (ORN), 33 with laparoscopic cryoablation (LC), 5 with cryoablation by open surgery (OC), and 15 with percutaneous cryoablation (PC) ( 7 under local anesthesia).

\subsection{Results}

Studies available in the peer-reviewed, published scientific literature are mostly in the form of case series studies. Some of the studies had small sample sizes and short, incomplete follow-up. Patients included in the studies were those with renal masses under $7 \mathrm{~cm}$ in diameter, located on the periphery of the kidney, as determined by diagnostic imaging studies. In many of the cases, a definitive histological diagnosis was not available until the chirurgic or the cryoablative procedure had been performed, and only a proportion of patients in each study had confirmed RCC. According to the literature, this can affect interpretation of results, as patients with benign lesions would likely have more favorable prognoses than those with malignant lesions. Moreover, the pooling of outcome data could make cryoablation appear more effective than if all patients had RCC (Gill et al., 2000; Rukstalis et al., 2001; Russo, 2005). To correct the results for this potential bias, controlled econometric estimates were conducted to calculate rates of recurrence and cancer-specific survival rates at five years. By cons, it was not possible to control for possible publication bias.

\subsubsection{Description of the cryoablation technique}

Cryoablation is indicated in patients who would become anephric following nephrectomy, either because they have a solitary functioning kidney or bilateral renal tumors. The procedure may also be considered in patients who have any comorbid situations that could lead to renal function deterioration in the future. Besides being an alternative to patients who cannot tolerate or may refuse surgical nephrectomy, cryoablation spares renal function and decreases pain, morbidity, hospital stay, and operation time. Its less invasive nature - especially when it is used percutaneously - makes cryoablation a preferred choice among approaches for elective interventions.

Cryoablation is a technique in which an average of 2 cryoprobes are inserted in the center of the tumor, either surgically or percutaneously pinpointed by computed tomography (CT), magnetic resonance imaging (MRI), and/or ultrasound. Cryoprobes are then cooled and heated by means of a gas, which cause cell death as a result of crystallization and recrystallization causing mechanical cell damage in the acute setting, and apoptosis and vascular amputation in the subacute setting. During the warming phase, an ischemia is created in the treated area because of vasoconstriction, endothelial injury, and microvascular thrombosis. If the freezing temperature is between $-19.4^{\circ} \mathrm{C}$ and $-40^{\circ} \mathrm{C}$ (Chosy et al. 1998), all tissues virtually turn to $100 \%$ necrosis. However, when one moves away from the point of application, the temperature increases, suggesting less efficiency as the tumor margin is approached. It is therefore important to apply an ice ball at least 6-8 millimeters beyond the tumor margin (Desai and Gill, 2002). In addition, double freezing, when compared with a single-freeze approach, has been shown to produce a larger area of necrosis in an animal model (Woolley et al., 2002). As a consequence, the (sonographic) determination of the ice ball is an essential part of the procedure.

The practice of cryoablation in conjunction with open surgery or laparoscopy is usually recommended when PC may cause intra-abdominal organ injury, the reason why PC is generally reserved for posterior tumors.

\subsubsection{Patients' characteristics}

Table 1 gives the characteristics of the patients: 
As compared to the standard approaches for the treatment of renal tumor, independent t-tests were used to compare all the means. The statistical significance level for each test was set at $\mathrm{P}<0.05$, based on a two-tailed test. Results show that:

- $\quad$ LC and PC are significantly used for older patients: the minimally invasive nature of cryoablation reduces certain risks associated with a conventional operation (bleeding, etc.) for a category of patients particularly at risk;

- There are systematically and significantly larger percentage of men to be treated with PC compared to other types of intervention. The fact that men are statistically almost two times more likely than women to have a malignancy (Snyder et al., 2006) could have consequences as regards to recurrence and specific-cancer survival rates. However, the percentage of malignant tumors is not significantly greater for patients benefiting from PC;

- The American Society of Anesthesiologist (ASA) score, reflecting the prevalence of medical comorbidities, is significantly higher for patients with LC and PC; no data are available for open cryoablation;

- With the exception of LPN, cryoablation - whatever the method used - is performed for tumors significantly smaller than for tumors using the standard approaches. Although cryoablation is rarely used for tumors larger than $4 \mathrm{~cm}$ because of technical constraints and larger costs (more cryoprobes, gas, etc.), this has already been performed on larger tumors; however, the potential number of failures is higher than with smaller tumors (Sewell and Shingleton, 2004; Sausville et al., 2008);

- $\quad$ The percentage of malignant tumors is generally significantly less important for patients benefiting from a cryoablation than for patients benefiting from a standard approach. Such a discrepancy could be explained by a probable overuse of minimally invasive techniques for small incidental masses for which open nephron-sparing surgery would not be considered. New data on the growth rate of tumors particularly $<2.5 \mathrm{~cm}$ would indicate that the majority remains indolent, and surveillance is indicated in those patients who are elderly or with significant comorbidity that precludes surgical intervention. Therefore, if cryoablation can treat these patients with a relatively small risk, this should lead to an increase in interventions for tumors suspected as malignant but whose final prognosis concludes with a benign condition.

\subsubsection{Clinical outcomes}

Table 2 gives the main clinical outcomes:

As compared to the standard approaches for the treatment of renal tumor, independent t-tests were used to compare all the means. The statistical significance level for each test was set at $\mathrm{P}<0.05$, based on a two-tailed test. Results show that:

- The operation time for PC is approximately one hour shorter than for other types of intervention. This gain is mainly due to a lesser need for mobilizing medical equipment, a practice technically more simple, and a much lower theoretical complication rate. The literature review revealed an average of two cycles of cooling-warming for cryoablation, then corresponding to a total of 19.8 minutes cooling time. In general, most studies indicate a time of warming equal to the time of cooling;

- A significant reduction of hospital stay was observed, in the range of 0.66 to 5.11 days less according to the type of operation performed. This reduction tends to indirectly confirm the less invasive nature of cryoablation to the extent that it should theoretically lead to a reduction in bleeding and peri- and postoperative complications;

- Insofar as cryoablation does not require ischemia to minimize the effect of a tumor excision (i.e. there is no tumor excision), this technique is regarded as risk-free, as compared to partial nephrectomy. This advantage of cryoablation is particularly important vis-à-vis the laparoscopic partial nephrectomy in that the latter is currently very difficult to perform owing to the great difficulty in obtaining renal parenchymal hemostasis during tumor excision and the consequent high risk of bleeding. Moreover, LPN may be associated with an increased risk of impairment of ipsilateral renal function owing to ischemic damage during warm ischemia time;

- A significantly lower blood loss was observed with cryoablation. Because cryoablation requires no renal parenchymal hemostasis, the low losses of blood observed are mainly due to the excisions performed by the open and laparoscopic surgery, and to the bleeding that may result from the withdrawal of cryoprobes;

- As regard the complication rates during and after the intervention, cryoablation does not present any significant difference with the standard approaches.

From the literature review, five grades of complications were considered leading to: I) oral medication or bedside care; II) intravenous therapy or thoracostomy tube; III) intubation, interventional radiology, endoscopy 
or reoperation; IV) major organ resection or chronic disability; V) death. Grades I and II are regarded as minor complications, whereas grades III to $\mathrm{V}$ are cases of major complications.

Results are at first quite surprising because a lower rate of complications for cryoablation was expected, particularly with PC, because of the less invasive nature of this technique. However, literature review suggests that the different types of complications were not consistently reported in all studies. This type of omission can mean two things: either a few complications are not reported - in particular certain minor complications and postoperative complications - or there were no complications. Faced with this lack of information, it is difficult to determine with accuracy and precision the rate of complications according to the kind of intervention.

\subsubsection{Oncological outcomes}

The follow-up of the studies is generally too short to obtain evidence on the rates of recurrence and survival associated with the different types of intervention. Indeed, the follow-up of a patient treated for a RCC should theoretically be for a period of at least 15 years because even late recurrences have been reported. Moreover, in a significant number of studies (Gill et al., 2005; Littrup et al., 2007), survival rates were calculated for populations in which some tumors are benign or indolent, which creates a problem of comparability between studies, especially as the results of biopsies are themselves subject to some uncertainty (Dechet et al., 2003).

In addition, the studies identified for this research present patients with features such as sex, age, tumor size, body mass index, ASA score, and so on, which can be very different and may have a significant effect on recurrence and specific-cancer survival rates. To control for this heterogeneity in patient characteristics and follow-up durations, the rate at 5 years for recurrence and specific-cancer survival for a representative patient was calculated from the coefficients obtained by each econometric estimation of these two dependant variables for each kind of intervention (Table 3). Econometric estimations are based on ordinary least squares (OLS) regression with nine independent variables and weighted by frequency. The nine variables are: duration of the follow-up, sex, age, tumor size, percentage of malignant tumors, ASA score, whether the kind of intervention is imperative or not, $\%$ of exophitic or peripheral tumors, body mass index. Furthermore, it must be noted here that although one of the most important determining factors for a five-year survival rate is the presence of kidney metastasis before surgery, and because none of the patients in the sample used for this study showed this characteristic, this factor could not affect the results provided in Table 3. Finally, to improve the accuracy of the estimations, a random data simulation for missing data was performed in Stata Version 8. Each missing data entry of the imputation variable is imputed by values randomly drawn from a subset of observed values, that is, its donor pool, with an assigned probability close to the missing data entry that is to be imputed. Each data simulation is based on the mean, the minimum and the maximum, and the standard deviation from its donor pool. New data are generated when the donor pool represents a minimum of one-third of the final sample. As a result, $27 \%$ of the data was generated in the final sample, which enabled to almost double the number of observations in the econometric estimates and to consider more variables of control. However, it is noted that the results obtained show very little difference with those obtained without simulation.

\subsubsection{Local or nearby recurrence rates}

With cryoablation, a recurrence is considered when the size of the lesion increases instead of decreasing or when a new cryoablation or standard surgery had to be performed. Although the increase of the size of the lesion observed by medical imaging is a good predictor of the recurrence of the disease in the case of cryoablation (Weight et al., 2008), this technique does not guarantee a result that is $100 \%$ accurate (Schwartz et al., 2006; Stein et al., 2008). Regarding standard techniques of nephrectomy, a recurrence is considered when, in a review of medical imaging, a new tumor appears at the site of resection (local) or at a location a few centimeters away from the site of resection (nearby).

Once controlled by the duration of the follow-up and the main characteristics of patients, the five-year local or nearby recurrence rate on a same kidney and the five-year specific-cancer survival rate for each kind of treatment techniques for renal tumors are obtained for patients sharing the same characteristics.

Rates of local or nearby recurrence provided in Table 3 indicate the lowest rates for the standard approaches. Within this category, rates for open nephrectomy are probably slightly higher than those of laparoscopic nephrectomy because of the generally more advanced stage of the tumors operated on, a feature that could not be controlled because of very less data from the reviewed studies.

Both open cryoablation and especially percutaneous cryoablation present particularly high rates of local or nearby recurrence (Note 2). As for open cryoablation, there are no objective reasons explaining why this rate is twice higher than that of LC and almost four times higher than that of OPN, except that the low number of 
observations that was found in the literature has led to a bias by not being representative of the reality, and that cryoablation is a new technology. On the contrary, with regard to PC, the difference is well explained by the number of technical failures of percutaneous procedures. The main reasons for these failures are twofold: 1) it is more difficult to accurately locate the tumor with medical imaging techniques than with a micro-camera (laparoscopy) or by the direct view of the surgeon (open surgery); 2) cryoablation is a new technology. The published studies are often based on the results of the first experiences of physicians who seem to have imperfect control of the percutaneous approach. This last point is probably decisive, because just as in the studies of Simmons and Gill (2007) and Thompson et al. (2005), it is very likely that a similar pattern will evolve with the technical failures of PC interventions. Indeed, these authors observed a sharp decline over time in rates of complications of laparoscopic partial nephrectomies because of the acquisition of greater experience by physicians.

Finally, if these results suggest that cryoablation techniques are - on the basis of recurrence - worse than standard techniques, it means that, for patients with local or nearby recurrence, these techniques mainly lead to delaying the date of the partial or radical nephrectomy using a standard technique without causing additional damage (i.e., there are no significantly more metastases with cryoablation than other techniques according to the meta-analysis performed by Kunkle et al. (2008)). For all other patients who did not require re-operation, cryoablation allows them to benefit from a minimally invasive technique.

\subsubsection{Specific-cancer rates}

According to Table 3, the five-year specific-cancer survival rate are quite similar, whatever the technique used. However, it should be noted that when there is a recurrence of the tumor or the development of metastases, the approach used by the physician to treat this new development of the kidney cancer is not necessarily the one that has been used at the outset, particularly when it was a cryoablation. Therefore, results of five-year specific-cancer survival rates for each initial approach are probably biased by the last approach in the case of multiple interventions. It is very likely that this bias applies only to cryoablation practices insofar as for open and laparoscopic nephrectomy, the main principles of oncological renal surgery are the same: primary access to the renal vasculature and their ligation before the kidney is mobilized and resected.

Other studies using more control variables to calculate or compare specific-cancer survival rates found results similar to those presented in Table 3. For example, in the study by Leibovich et al. (2004), the five-year specific-cancer survival rates following an open partial or radical nephrectomy are, respectively, $98 \%$ and $86 \%$, but after adjusting the data by the patients' characteristics, this difference is not statistically significant (Note 3 ).

\section{Conclusion}

Although there are still concerns about the safety of the LPN - longer warm ischemia times compared with OPN and the reported high rate of complications -, LPN is now considered by a growing number of specialists as a gold standard for small renal tumors (Shuford et al., 2004). Thus, it is from that point of reference that the technique of cryoablation should be compared. Principally the new technique has to address two points: is the cryoablation approach a safe procedure and are the oncological results equal to standard surgery?

It seems that the answer to the first question is positive insofar as a large number of studies indicate complications rates and hospitalization times lower or identical for cryoablation as compared to standard approaches. The main advantages of cryoablation as compared to laparoscopic and open nephrectomy are: less postoperative pain, a faster recovery, and a more rapid return to normal activities (Ono et al., 1999). These advantages and a consequent reduced period of convalescence not only reduce direct medical costs for hospital and patients, but also reduce the economic losses related to a long-term morbidity. In contrast, hemorrhage around the cryolesion may inhibit accurate post-treatment size measurements (Russo, 2005), as well as the removal of the cryoprobe creates a potential risk of bleeding and dissemination of cancer cells along its route.

The answer to the second question is more indecisive. Indeed, if the current evidence suggests that cryotherapy for renal cancer is able to ablate tumor tissues and that the safety of the procedure is adequate, its long-term efficacy has yet to be established. The results provided by Table 3 indicate quasi identical values of the five-year specific-cancer survival rates for both cryoablation and standard techniques, but much higher values of the five-year local or nearby recurrence rates for cryoablation, especially for PC. To reduce this problem, the team NICE (2007) recommends that the procedure should only be offered after evaluation by a multidisciplinary team, which should include an urologist, an oncologist, and an interventional radiologist. Nevertheless, given the fast pace of change in the cryoablation technology and its relative simplicity of use, more and more patients are expected in the near future to benefit from this technique with the same degree of efficiency than the current standard techniques (Kunkle et al., 2008). 
Finally, it is clear from this literature review that cryoablation is an interesting alternative as compared to current standard approaches (i.e., open and laparoscopic nephrectomy). Not only this practice is recognized as safe and minimally invasive, but, in the specific case of percutaneous cryoablation, it also has the advantage to be potentially (i.e. with a more stringent selection of patients) less costly for the hospital. However, as its long-term effectiveness is not yet fully established, the authors believe that the practice of cryoablation must be excluded for the complex renal mass such as hilar tumors, partially cystic tumors, central tumors, or tumors larger than 4 $\mathrm{cm}$.

\section{References}

Benson, K., \& Hartz, A. J. (2000). A comparison of observational studies and randomized controlled trials. $N$ Engl J Med, 342, 1878-86.

Bosniak, M. A., Krinsky, G. A., \& Waisman, J. (1996). Management of small incidental renal parenchymal tumors by watchful waiting in selected patients based on observation of tumor growth rates. J Urol, 155, 584 .

Chosy, S. G., Nakada, S. Y., Lee, F. T. et al. (1998). Monitoring renal cryosurgery: predictors of tissue necrosis in swine. $J$ Urol, 159, 1370-74.

Chow, W. H., Devesa, S. S., Waren, J.L. et al. (1999). Rising incidence of renal cell cancer in the United States. JAMA, 281, 1628-31.

Concato, J., Shah, N., \& Horwitz, R. I. (2000). Randomized, controlled trials, observational studies, and the hierarchy of research designs. N Engl J Med, 342, 1887-92.

Dechet, C. B., Zincke, H., Sebo, T. J. et al. (2003). Prospective analysis of computerized tomography and needle biopsy with permanent sectioning to determine the nature of solid renal masses in adults. $J$ Urol, 169, 71-74.

Desai, M. M., \& Gill, I. S. (2002). Current status of cryoablation and radiofrequency ablation in the management of renal tumors. Curr Opin Urol, 12, 387-93.

Frank, I., Blute, M. L., Cheville, J. C. et al. (2003). Solid renal tumors: an analysis of pathological features related to tumor size. $J$ Urol, 170, 2217-20.

Gill, I. S., Novick, A. C., Meraney, A. M. et al. (2000). Laparoscopic renal cryoablation in 32 patients. Urology, 56(5), 748-53.

Gill, I. S., Remer, E. M., Hasan, W. A. et al. (2005). Renal cryoablation: outcome at 3 years. J Urol, 173, 1903-07.

Hankey, B. F., Feuer, E. J., Clegg, L. X. et al. (1999). Cancer surveillance series: interpreting trends in prostate cancer - part I: Evidence of the effects of screening in recent prostate cancer incidence, mortality, and survival rates. $J$ Natl Cancer Inst, 91, 1017-24.

Israel, G. M., \& Bosniak, M. A. (2005). An update of the Bosniak renal cyst classification system. Urology, 66, 484-88.

Jemal, A., Murray, T., Samuels, A. et al. (2003). Cancer statistics. CA Cancer J Clin, 53, 5-26.

Kunkle, D. A., Egleston, B. L., \& Uzzo, R. G. (2008). Excise, Ablate or Observe: The Small renal Mass Dilemma - A Meta-Analysis and Review. J Uro, 179, 1227-34.

Leibovich, B. C., Blute, M. L., Cheville, J. C. et al. (2004). Nephron sparing surgery for appropriately selected renal cell carcinoma between 4 and $7 \mathrm{~cm}$ resulting in outcome similar to radical nephrectomy. $J$ Urol, 171, 1066-70.

Littrup, P. J., Ahmed, A., Aoun, H. D. et al. (2007). CT-guided Percutaneous Cryotherapy of Renal Masses. J Vasc Interv Radiol, 18(3), 383-92.

National Institute for Health and Clinical Excellence (NICE). (2007). Cryotherapy for renal cancers: guidance. Accessed October 7, 2008. Available at URL address: http://www.nice.org.uk/guidance/IPG207/guidance/pdf/English.

Ono, Y., Kinukawa, T., Hattori, R. et al. (1999). Laparoscopic radical nephrectomy for renal cell carcinoma: a five-year experience. Urology, 53(2), 280-86.

Pantuck, A. J., Zisman, A., \& Belldegrun, A. S. (2001). The changing natural history of renal cell carcinoma. $J$ Urol, 52, 447-50. 
Parkin, D. M., Whelan, S. L., Ferlay, J. et al. (2002). Cancer Incidence in Five Continents. IARC Scientific Publication, 155.

Pocock, S. J., \& Elbourne, D.R. (2000). Randomized trials or observational tribulations? N Engl J Med, 342, $1907-9$.

Rukstalis, D. B., Kaouk, J. H., \& Gill, I. S. (2006). Introduction. Urology, 68(1A suppl), 1.

Rukstalis, D. B., Khorsandi, M., Garcia, F. U. et al. (2001). Clinical experience with open renal cryoablation. Urology, 57, 34-39.

Russo, P. (2000). Renal cell carcinoma: presentation, staging, and surgical treatment. Semin Oncol, 27, 160-76.

Russo, P. (2005). Renal cryoablation: study with care - proceed with caution. Urology, 65 419-21

Sausville, J., Borin, J., \& Phelan, M. (2008). Initial experience in renal cryosurgery for large renal lesion. J Urol, 179(4 suppl), 288.

Schwartz, B. F., Rewcastle, J. C., Powell, T. et al. (2006). Cryoablation of small peripheral renal masses: a retrospective analysis. Urology, 68(1 suppl), 14-18.

Sewell, P., \& Shingleton, W. (2004). Five-year treatment success and survival of patients treated with percutaneous IMRI guided and monitored renal cell carcinoma cryoablation. BJU Int, 94, 106.

Shuford, M. D., McDougall, E. M., Chang, S. S. et al. (2004). Complications of contemporary radical nephrectomy: comparison of open vs. laparoscopic approach. Urol Oncol, 22, 121-26.

Simmons, M. N., \& Gill, I. S. (2007). Decreased Complications of Contemporary Laparoscopic Partial Nephrectomy: Use of a Standardized Reporting System. J Urol, 177, 2067-73.

Snyder, M. E., Bach, A., Kattan, M. W. et al. (2006). Incidence of benign lesions for clinically localized renal masses smaller than $7 \mathrm{~cm}$ in radiological diameter: influence of sex. $J$ Urol, 176(6 pt 1), 2391-95.

Stein, A. J., Mayes, J. M., Mouraviev, V. et al. (2008). Persistent contrast enhancement several months after laparoscopic cryoablation of the small renal mass may not indicate remaining tumor. $J$ Urol, 179(4 suppl), 728.

Thompson, R. H., Leibovich, B. C., Lohse, C. M. et al. (2005). Complications of contemporary open nephron sparing surgery: a single institution experience. $J$ Urol, 174, 855.

Weight, C. J., Kaouk, J. H., Hegarty, N. J. et al. (2008). Correlation of Radiographic Imaging and Histopathology Following Cryoablation and Radio Frequency Ablation for renal Tumors. J Urol, 179, 1277-83.

Woolley, M. L., Schulsinger, D. A., Durand, D. B. et al. (2002). Effect of freezing parameters (freeze cycle and thaw process) on tissue destruction following renal cryoablation. $J$ Endourol, 16, 519-22.

\section{Notes}

Note 1. http://www.strobe-statement.org/Checklist.html

Note 2. The meta-analysis performed by Kunkle et al. (2008) also indicates that the local recurrence rate is significantly higher with cryoablation. However, it is not distinguished in this study if the approach is open, laparoscopic or percutaneous.

Note 3. In the same study, the rate at 5 years of non-recurrence of renal tumors is $94 \%$ for partial nephrectomy and $98 \%$ for radical nephrectomy. 
Table 1. Main patients' characteristics

\begin{tabular}{|c|c|c|c|c|c|c|c|c|c|c|c|c|c|c|}
\hline & \multicolumn{2}{|c|}{ LPN } & \multicolumn{2}{|c|}{ LRN } & \multicolumn{2}{|c|}{ OPN } & \multicolumn{2}{|c|}{ ORN } & \multicolumn{2}{|c|}{ LC } & \multicolumn{2}{|c|}{$\mathrm{OC}$} & \multicolumn{2}{|c|}{$\mathrm{PC}$} \\
\hline & Mean & S.D. & Mean & S.D. & Mean & S.D. & Mean & S.D. & Mean & S.D. & Mean & S.D. & Mean & S.D. \\
\hline \multirow[t]{2}{*}{ Age (years) } & 59.6 & 4.4 & 60.3 & 3.9 & 60.1 & 4.1 & 60.8 & 3.5 & 65.7 & 5.1 & 62.9 & 2.6 & 67.1 & 4.9 \\
\hline & {$[50-76]$} & [71] & [51-67] & [33] & {$[51-70]$} & [36] & [49-66] & [27] & {$[50-76]$} & [29] & [60-67] & [5] & {$[58-73]$} & [13] \\
\hline \multirow[t]{2}{*}{ Male (\%) } & 61.1 & 13.5 & 60.1 & 9.6 & 65.9 & 7.2 & 61.7 & 9.6 & 60.5 & 13.9 & 55.3 & 4.8 & 73 & 10.7 \\
\hline & {$[25-88]$} & [57] & {$[36-76]$} & [27] & {$[46-80]$} & [29] & {$[26-72]$} & [23] & [33-85] & [23] & {$[50-60]$} & [3] & [50-92] & [11] \\
\hline \multirow[t]{2}{*}{ ASA score } & 2.4 & 0.3 & 2.4 & 0.3 & 2.5 & 0.3 & 2.4 & 0.3 & 2.6 & 0.3 & NA & NA & 3 & 0 \\
\hline & [1.8-3] & {$[25]$} & [1.9-2.9] & [18] & [2-3] & [12] & {$[1.8-2.8]$} & [11] & [2-3] & [10] & & & [3-3] & [2] \\
\hline Tumor size & 2.7 & 0.9 & 5.2 & 2.2 & 3.4 & 0.7 & 5.4 & 2.5 & 2.6 & 0.7 & 2.3 & 0.3 & 2.9 & 1 \\
\hline$(\mathrm{cm})$ & {$[1.8-8.1]$} & [71] & {$[2.8-15]$} & [29] & $2.2-5.3$ & [38] & [2.6-14] & [26] & [1.9-6] & [33] & {$[2-2.6]$} & [5] & [2.1-6] & [14] \\
\hline Malignant & 77.2 & 14 & 88.3 & 13.4 & 90.2 & 11.4 & 96.6 & 7.2 & 61.9 & 11.6 & 70.6 & 8.4 & 81.1 & 17.3 \\
\hline$(\%)$ & [36-100] & [69] & {$[52-100]$} & [28] & 67-100] & [36] & {$[70-100]$} & [27] & [36-84] & [28] & [59-79] & [5] & {$[50-100]$} & [9] \\
\hline
\end{tabular}

Notes: Brackets in the « Mean » columns are for Minimum and Maximum; Brackets in the « Standard Deviation » columns are for the number of studies observed.

Table 2. Main clinical outcomes

\begin{tabular}{|c|c|c|c|c|c|c|c|c|c|c|c|c|c|c|}
\hline & \multicolumn{2}{|c|}{ LPN } & \multicolumn{2}{|c|}{ LRN } & \multicolumn{2}{|c|}{ OPN } & \multicolumn{2}{|c|}{ ORN } & \multicolumn{2}{|c|}{$\mathrm{LC}$} & \multicolumn{2}{|c|}{$\mathrm{OC}$} & \multicolumn{2}{|c|}{$\mathrm{PC}$} \\
\hline & Mean & S.D. & Mean & S.D. & Mean & S.D. & Mean & S.D. & Mean & S.D. & Mean & S.D. & Mean & S.D. \\
\hline Operation & 186 & 53.8 & 189 & 63.5 & 201 & 52.9 & 171 & 36.5 & 192 & 49.9 & 218 & 0 & 135 & 49.6 \\
\hline time (min) & [84-324] & {$[65]$} & {$[70-330]$} & {$[27]$} & {$[122-275]$} & [14] & [118-222] & {$[12]$} & (115-306] & {$[21]$} & {$[-]$} & [1] & $77-235]$ & [8] \\
\hline Hospital & 4.2 & 1.9 & 3.6 & 1.6 & 6.5 & 2.2 & 6.5 & 1.8 & 2.9 & 1.1 & 4 & 1.1 & 1.4 & 0.6 \\
\hline stay (days) & [1.7-10] & {$[54]$} & {$[1.4-7.4]$} & {$[28]$} & [4-14] & [19] & {$[3.6-9.7]$} & {$[15]$} & [1-5] & {$[25]$} & [3-5.7] & [5] & {$[0.5-2.4]$} & [10] \\
\hline Blood losses & 259 & 136 & 182 & 65 & 452 & 187 & 405 & 114 & 88.1 & 32 & 132 & 59 & 5 & 7 \\
\hline$(\mathrm{ml})$ & $20-725]$ & {$[62]$} & {$[90-372]$} & {$[26]$} & {$[250-865]$} & [13] & $238-640]$ & {$[13]$} & [35-178] & {$[20]$} & {$[58-200]$} & [4] & [0-10] & [2] \\
\hline$\%$ major & 2.4 & 4.2 & 3.4 & 3.4 & 2.4 & 3.6 & 4.2 & 4.3 & 2.7 & 3.8 & 0 & 0 & 3.6 & 5.6 \\
\hline complicat $^{\circ}$ & {$[0-16.7]$} & {$[61]$} & {$[0-11]$} & {$[30]$} & {$[0-11]$} & {$[18]$} & {$[0-14]$} & {$[16]$} & [0-13.3] & {$[28]$} & {$[-]$} & [5] & {$[0-20]$} & [14] \\
\hline$\%$ minor & 6.2 & 10.7 & 6.2 & 7.5 & 8.7 & 11.1 & 9.5 & 11.7 & 6.2 & 10.5 & 12.8 & 9.4 & 8.2 & 9.7 \\
\hline complicat $^{\circ}$ & {$[0-62.5]$} & {$[60]$} & {$[0-34.4]$} & {$[28]$} & {$[0-48.1]$} & {$[22]$} & {$[0-45.5]$} & {$[17]$} & {$[0-35]$} & {$[27]$} & {$[0-25]$} & [5] & [0-30] & [13] \\
\hline$\%$ post-op & 14.7 & 14.9 & 9.3 & 6.8 & 15.2 & 8.7 & 8.9 & 5.8 & 13 & 15.8 & 9.2 & 8 & 7.8 & 6.9 \\
\hline complicat $^{\circ}$ & {$[0-75]$} & [57] & {$[1.6-30]$} & [18] & [3.4-34] & {$[20]$} & [1.6-19] & [11] & [0-67] & [24] & {$[0-14]$} & [3] & {$[0-20]$} & [9] \\
\hline
\end{tabular}


Table 3. Five-year local or nearby recurrence rates on a same kidney and specific-cancer survival rates

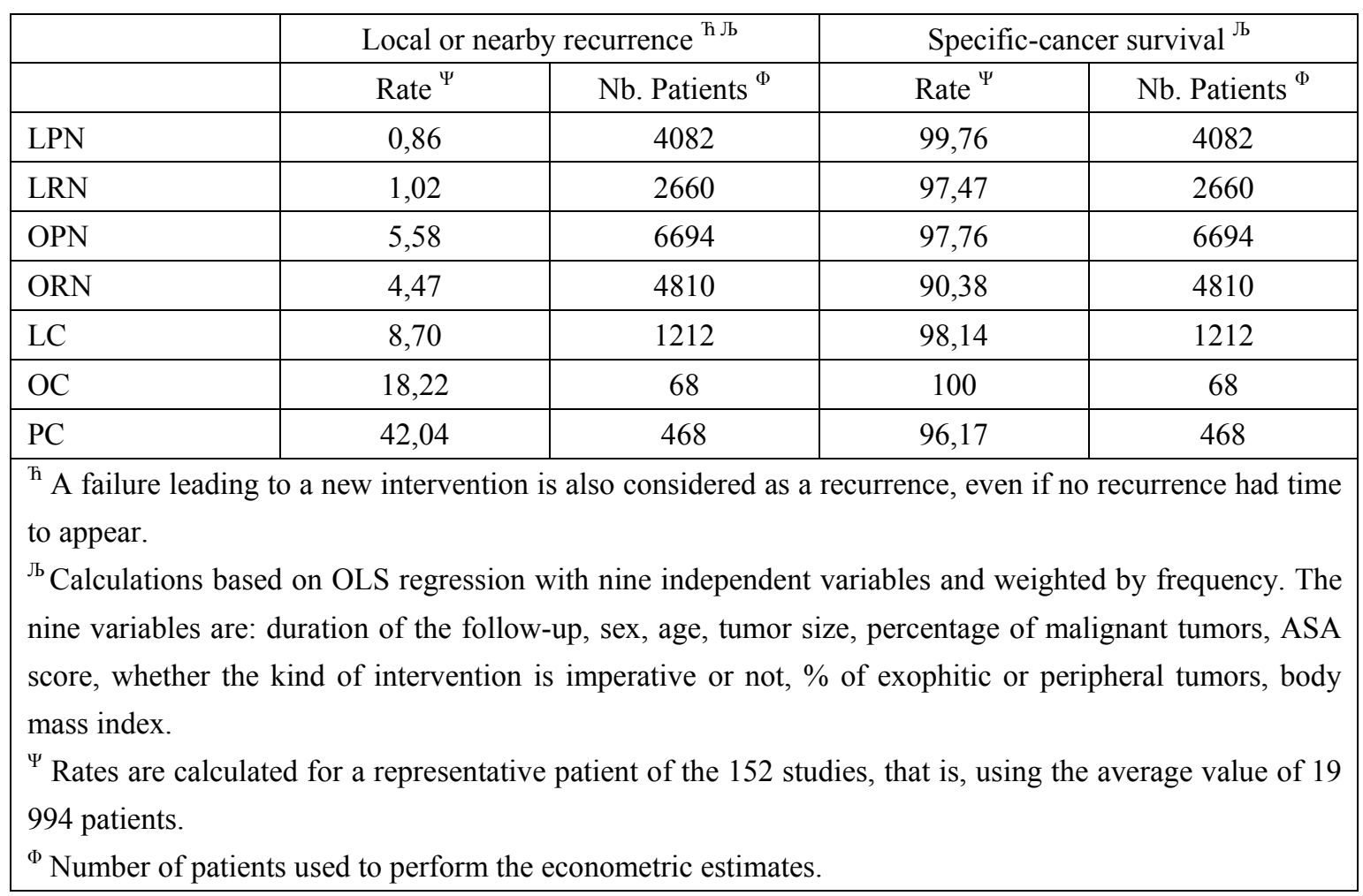

Annex 1. List of studies included in the meta-analysis

\begin{tabular}{|c|c|c|c|c|c|}
\hline Authors & Period & Place & Study design & $\begin{array}{l}\text { Number } \\
\text { operation }\end{array}$ & of Type of operation \\
\hline $\begin{array}{l}\text { Abbou et al. } \\
\text { (1999) }\end{array}$ & $95-98$ & Créteil, France & Retrospective & $29-29$ & LRN-ORN \\
\hline $\begin{array}{l}\text { Abukora et al. } \\
(2005)\end{array}$ & $94-04$ & Linz, Austria & Retrospective & 78 & LPN \\
\hline $\begin{array}{l}\text { Adkins et al. } \\
(2003)\end{array}$ & $95-00$ & Nashville, TN & & 30 & OPN \\
\hline $\begin{array}{l}\text { Allaf et al. } \\
(2004)\end{array}$ & $96-01$ & $\begin{array}{l}\text { Baltimore, } \\
\text { Maryland }\end{array}$ & Retrospective & 48 & LPN \\
\hline $\begin{array}{l}\text { Anast et al. } \\
(2004)\end{array}$ & $98-03$ & $\begin{array}{ll}\text { San } & \text { Francisco, } \\
\text { CA } & \\
\end{array}$ & Retrospective & $44-117$ & LPN-LRN \\
\hline $\begin{array}{l}\text { Atwell et al. } \\
(2008)\end{array}$ & 03-07 & $\begin{array}{l}\text { Mayo clinic, } \\
\text { Rochester, } \\
\text { Minnesota }\end{array}$ & Retrospective & 113 & $\mathrm{PC}$ \\
\hline $\begin{array}{l}\text { Bachmann } e t \\
\text { al. }(2005)\end{array}$ & $02-$ & $\begin{array}{l}\text { Basel, Suisse - } \\
\text { Munich, All }\end{array}$ & & 7 & $\mathrm{LC}$ \\
\hline $\begin{array}{l}\text { Bandi et al. } \\
(2008)\end{array}$ & $00-06$ & $\begin{array}{l}\text { Madison, } \\
\text { Wisconsin }\end{array}$ & Retrospective & $58-20$ & LC-PC \\
\hline $\begin{array}{l}\text { Bang et al. } \\
(2008)\end{array}$ & & Seoul, Corea & & $39-48$ & LPN-OPN \\
\hline $\begin{array}{l}\text { Barbalias et al. } \\
\text { (1999) }\end{array}$ & $86-96$ & Greece & $\begin{array}{l}\text { Retrospective, } \\
\text { paired }\end{array}$ & $41-48$ & OPN-ORN \\
\hline $\begin{array}{l}\text { Baumert et al. } \\
\text { (2007) }\end{array}$ & $03-05$ & $\begin{array}{lr}\text { Paris } & \text { Saint } \\
\text { Joseph Hospital } \\
\text { Trust, France - } \\
\text { Cambridge, UK }\end{array}$ & Prospective & 40 & LPN \\
\hline
\end{tabular}




\begin{tabular}{|c|c|c|c|c|c|}
\hline $\begin{array}{l}\text { Beasley et al. } \\
(2004)\end{array}$ & $99-03$ & $\begin{array}{l}\text { London } \quad \& \\
\text { Hamilton, } \\
\text { Canada }\end{array}$ & $\begin{array}{l}\text { Retrospective, } \\
\text { paired }\end{array}$ & $22-27$ & OPN-LPN \\
\hline $\begin{array}{l}\text { Becker et al. } \\
(2006 \mathrm{a})\end{array}$ & $75-02$ & $\begin{array}{ll}\text { Saarland et } \\
\text { Stuttgart, } \\
\text { Germany }\end{array}$ & Retrospective & $241-369$ & OPN-ORN \\
\hline $\begin{array}{l}\text { Becker et al. } \\
(2006 \mathrm{~b})\end{array}$ & 75-04 & $\begin{array}{l}\text { Saarland et } \\
\text { Stuttgart, } \\
\text { Germany }\end{array}$ & Retrospective & 69 & OPN \\
\hline $\begin{array}{l}\text { Beemster } \text { et al. } \\
(2008)\end{array}$ & $03-06$ & $\begin{array}{l}\text { Amsterdam, } \\
\text { Holland }\end{array}$ & & 26 & $\mathrm{LC}$ \\
\hline $\begin{array}{l}\text { Belldegrun et } \\
\text { al.(1999) }\end{array}$ & $80-97$ & $\begin{array}{l}\text { University of } \\
\text { California-Los } \\
\text { Angeles, CA }\end{array}$ & $\begin{array}{l}\text { Retrospective, } \\
\text { paired }\end{array}$ & $146-125$ & OPN-ORN \\
\hline $\begin{array}{l}\text { Bensalah et al. } \\
(2008)\end{array}$ & $03-07$ & Dallas, Texas & Retrospective & $61-67-61-48$ & LPN-LRN-OPN-ORN \\
\hline $\begin{array}{l}\text { Berger et al. } \\
(2008)\end{array}$ & $00-06$ & $\begin{array}{l}\text { New York } \\
\text { University } \\
\text { School of } \\
\text { Medicine, NY } \\
\end{array}$ & Retrospective & 164 & LRN \\
\hline $\begin{array}{l}\text { Bermudez et al. } \\
\text { (2003) }\end{array}$ & 01-02 & $\begin{array}{l}\text { Institut } \\
\text { Mutualiste } \\
\text { Montsouris, } \\
\text { Paris, France }\end{array}$ & Prospective & 19 & LPN \\
\hline $\begin{array}{lll}\begin{array}{l}\text { Bollens } \\
(2007)\end{array} & & a l . \\
\end{array}$ & $02-06$ & $\begin{array}{l}\text { Brussels, } \\
\text { Belgium }\end{array}$ & Retrospective & 39 & LPN \\
\hline $\begin{array}{lll}\begin{array}{l}\text { Bolte } \\
(2006)\end{array} & \text { et } & \text { al. } \\
\end{array}$ & $00-04$ & $\begin{array}{l}\text { Madison, } \\
\text { Wisconsin }\end{array}$ & & 18 & $\mathrm{LC}$ \\
\hline $\begin{array}{lll}\text { Brown } & \text { et } & \text { al. } \\
(2004) & & \\
\end{array}$ & $00-02$ & $\begin{array}{l}\text { Philadelphia, } \\
\text { Pennsylvania }\end{array}$ & Retrospective & 30 & LPN \\
\hline $\begin{array}{lll}\begin{array}{l}\text { Butler } \\
(1995)\end{array} & \text { et } & \text { al. } \\
\end{array}$ & $75-92$ & Cleveland, Ohio & $\begin{array}{l}\text { Retrospective, } \\
\text { paired }\end{array}$ & 42 & ORN \\
\hline $\begin{array}{l}\text { Caddedu et al. } \\
\text { (1998) }\end{array}$ & $91-97$ & $\begin{array}{l}\text { Baltimore, } \\
\text { Maryland - St. } \\
\text { Louis, Missouri } \\
\text { - Saskatoon, } \\
\text { Saskatchewan - } \\
\text { Nagoya, Japan - } \\
\text { Innsbruck, } \\
\text { Austria }\end{array}$ & Retrospective & 157 & LRN \\
\hline $\begin{array}{l}\text { Caviezel et al. } \\
(2008)\end{array}$ & & $\begin{array}{l}\text { Geneva, } \\
\text { Switzerland }\end{array}$ & Retrospective & 7 & $\mathrm{PC}$ \\
\hline $\begin{array}{lll}\begin{array}{l}\text { Cestari } \\
(2007)\end{array} & & a l . \\
\end{array}$ & $00-06$ & Turin, Italy & Prospective & 86 & $\mathrm{LC}$ \\
\hline 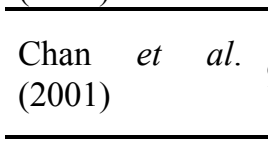 & $91-99$ & $\begin{array}{l}\text { Baltimore, } \\
\text { Maryland - } \\
\text { Atlanta, USA } \\
\end{array}$ & Retrospective & 54 & ORN \\
\hline $\begin{array}{l}\text { Chapman et al. } \\
(2008)\end{array}$ & $04-07$ & Buffalo, NY & Retrospective & 100 & LRN \\
\hline $\begin{array}{lll}\begin{array}{l}\text { Chavla } \\
(2006)\end{array} & \text { et } & \\
\end{array}$ & $00-05$ & $\begin{array}{l}\text { St-Louis, } \\
\text { Missouri } \\
\end{array}$ & Retrospective & 12 & LC \\
\hline $\begin{array}{lll}\begin{array}{l}\text { Cicco } \\
(2001)\end{array} & \text { et } & \text { al. } \\
\end{array}$ & $95-99$ & Creteil, France & Retrospective & 50 & LRN \\
\hline $\begin{array}{l}\text { Colombo et al. } \\
(2008)\end{array}$ & $97-99$ & Cleveland, Ohio & Retrospective & $63-53$ & LRN-ORN \\
\hline
\end{tabular}




\begin{tabular}{|c|c|c|c|c|c|}
\hline $\begin{array}{l}\text { Colon \& Fuchs } \\
(2003)\end{array}$ & 01-01 & $\begin{array}{l}\text { Los angeles, CA } \\
\text { - Brooklyn, NY } \\
\end{array}$ & & 8 & $\mathrm{LC}$ \\
\hline $\begin{array}{l}\text { D'armiento et } \\
\text { al. (1997) }\end{array}$ & 88-93 & Oxford, UK & $\begin{array}{l}\text { Prospective, } \\
\text { randomised }\end{array}$ & $19-21$ & OPN-ORN \\
\hline $\begin{array}{l}\text { Davol, Fulmer } \\
\& \quad \text { Rukstalis } \\
(2006) \\
\end{array}$ & $96-02$ & $\begin{array}{l}\text { Danville, } \\
\text { Pennsylvania }\end{array}$ & Retrospective & $24-24$ & LC-OC \\
\hline $\begin{array}{l}\text { Deger et al. } \\
(2008)\end{array}$ & 02-07 & $\begin{array}{l}\text { Berlin, } \\
\text { Germany } \\
\text { Basel, } \\
\text { Switzerland }\end{array}$ & & 163 & LRN \\
\hline $\begin{array}{l}\text { Derweesh et al. } \\
(2006)\end{array}$ & $98-06$ & $\begin{array}{l}\text { Memphis, } \\
\text { Tennessee } \\
\end{array}$ & Retrospective & $9-13$ & LC-PC \\
\hline $\begin{array}{lll}\begin{array}{l}\text { Desai } \\
(2005)\end{array} & \text { et } & \text { al. } \\
\end{array}$ & $97-04$ & Cleveland, Ohio & Retrospective & $78-153$ & LC-LPN \\
\hline $\begin{array}{lll}\begin{array}{l}\text { Desai } \\
(2008)\end{array} & \text { et } & \text { al. } \\
\end{array}$ & $00-07$ & $\begin{array}{l}\text { Phoenix, } \\
\text { Arizona }\end{array}$ & Retrospective & 80 & LPN \\
\hline $\begin{array}{l}\text { Doublet \& } \\
\text { Belair (2000) }\end{array}$ & $94-98$ & $\begin{array}{l}\text { Hôpital Tenon, } \\
\text { Paris, France - } \\
\text { Montréal, } \\
\text { Canada }\end{array}$ & & 55 & LRN \\
\hline $\begin{array}{l}\text { Dunn et } a l . \\
(2000)\end{array}$ & $90-99$ & $\begin{array}{l}\text { St. } \\
\text { Missouri Louis, } \\
\text { Tanta, Egypt } \\
\end{array}$ & Retrospective & $61-33$ & LRN-ORN \\
\hline $\begin{array}{l}\text { Eschholz et al. } \\
(2005)\end{array}$ & $01-$ & $\begin{array}{l}\text { Blankenhain, } \\
\text { Germany }\end{array}$ & & 34 & LPN \\
\hline $\begin{array}{lll}\text { Feder } & \text { et } & \text { al. } \\
(2008) & & \\
\end{array}$ & 95-06 & $\begin{array}{c}\text { Jacksonville, } \\
\text { FL - Bronx, NY }\end{array}$ & Retrospective & $45-43$ & LRN-ORN \\
\hline $\begin{array}{l}\text { Fergany et al. } \\
(2006)\end{array}$ & 80-02 & Cleveland, Ohio & Retrospective & 400 & OPN \\
\hline $\begin{array}{lll}\begin{array}{l}\text { Finley } \\
(2008)\end{array} & \text { et } & a l . \\
\end{array}$ & 03-07 & Orange, CA & Retrospective & $20-18$ & LC-PC \\
\hline $\begin{array}{l}\text { Funahashi et al. } \\
(2009)\end{array}$ & $05-07$ & $\begin{array}{ll}\text { Nagoya } & \text { et } \\
\text { Aichi, Japan } & \\
\end{array}$ & Prospective & $12-20$ & LPN-OPN \\
\hline $\begin{array}{l}\text { Gallucci et al. } \\
(2007)\end{array}$ & 03-05 & Rome, Italy & & 50 & LPN \\
\hline $\begin{array}{l}\text { Georgiades et } \\
\text { al. }(2008)\end{array}$ & & $\begin{array}{l}\text { Baltimore, } \\
\text { Maryland }\end{array}$ & Retrospective & & $\mathrm{PC}$ \\
\hline $\begin{array}{l}\text { Gettman et al. } \\
(2004)\end{array}$ & 02-03 & $\begin{array}{l}\text { Innsbruck, } \\
\text { Austria }\end{array}$ & Retrospective & 13 & LPN \\
\hline $\begin{array}{l}\text { Gill et } a l . \\
(2007)\end{array}$ & $98-05$ & $\begin{array}{l}\text { Cleveland, Ohio } \\
-\quad \text { Baltimore, } \\
\text { Maryland - } \\
\text { Mayo Clinic, } \\
\text { Rochester, } \\
\text { Minnesota }\end{array}$ & $\begin{array}{l}\text { Retrospective } \\
\text { and Prospective }\end{array}$ & $771-1029$ & LPN-OPN \\
\hline $\begin{array}{l}\text { Goel \& Kaouk } \\
(2008)\end{array}$ & $07-$ & Cleveland, Ohio & Prospective & 6 & $\mathrm{LC}$ \\
\hline $\begin{array}{l}\text { Guillonneau et } \\
\text { al. (2003) }\end{array}$ & $97-02$ & $\begin{array}{l}\text { Institut } \\
\text { Mutualiste } \\
\text { Montsouris, } \\
\text { Paris, France }\end{array}$ & Retrospective & 28 & LPN \\
\hline
\end{tabular}




\begin{tabular}{|c|c|c|c|c|c|}
\hline $\begin{array}{l}\text { Gupta et al. } \\
(2006)\end{array}$ & 03-04 & $\begin{array}{l}\text { Baltimore, } \\
\text { Maryland } \\
\end{array}$ & & 12 & $\mathrm{PC}$ \\
\hline $\begin{array}{lll}\begin{array}{l}\text { Hacker } \\
(2007)\end{array} & \text { et } & \text { al. } \\
\end{array}$ & 04-05 & Linz, Austria & & 25 & LPN \\
\hline $\begin{array}{l}\text { Harmon et al. } \\
(2000)\end{array}$ & $98-99$ & $\begin{array}{l}\text { San Antonio, } \\
\text { Texas } \\
\text { Baltimore, } \\
\text { Maryland } \\
\end{array}$ & Retrospective & 15 & LPN \\
\hline $\begin{array}{l}\text { Hegarty et al. } \\
(2006)\end{array}$ & $97-$ & Cleveland, Ohio & Retrospective & 161 & $\mathrm{LC}$ \\
\hline $\begin{array}{l}\text { Heinrich et al. } \\
(2006)\end{array}$ & 01-05 & $\begin{array}{l}\text { Wurzburg, } \\
\text { Germany }\end{array}$ & Retrospective & 40 & LPN \\
\hline $\begin{array}{l}\text { Henderson et } \\
\text { al. (2008) }\end{array}$ & $97-06$ & $\begin{array}{l}\text { Ann Arbor, } \\
\text { Michigan - } \\
\text { Redhill, Surrey, } \\
\text { UK }\end{array}$ & Retrospective & 13 & LPN \\
\hline Herr (1999) & $79-97$ & $\begin{array}{l}\text { Memorial } \\
\text { Sloan-Kettering } \\
\text { Cancer Center, } \\
\text { New York } \\
\end{array}$ & Retrospective & 70 & OPN \\
\hline $\begin{array}{l}\text { Hollingsworth } \\
\text { et al. (2006) }\end{array}$ & $98-03$ & $\begin{array}{l}\text { Ann Arbor, } \\
\text { Michigan }\end{array}$ & Retrospective & $65-106-73-92$ & LPN-LRN-OPN-ORN \\
\hline $\begin{array}{lll}\text { Hruby } & \text { et } & a l . \\
(2006) & & \\
\end{array}$ & 00-04 & NY, NY & Retrospective & $12-11$ & LPN-LC \\
\hline $\begin{array}{l}\begin{array}{l}\text { Hwang et } \\
(2006)\end{array} \\
\end{array}$ & & New jersey & Prospective & 23 & $\mathrm{LC}$ \\
\hline $\begin{array}{l}\text { Itoh et al. } \\
(2002)\end{array}$ & & $\begin{array}{l}\text { Yamagata, } \\
\text { Japan }\end{array}$ & & 6 & LPN \\
\hline $\begin{array}{ll}\text { Janetschek et } \\
\text { al. }(2000)\end{array}$ & $94-98$ & $\begin{array}{l}\text { Innsbruck, } \\
\text { Austria } \\
\end{array}$ & Retrospective & $25-73$ & LPN-LRN \\
\hline $\begin{array}{lll}\begin{array}{l}\text { Javidan et } \\
(1999)\end{array} & \text { al. } \\
\end{array}$ & $68-94$ & $\begin{array}{l}\text { Detroit, } \\
\text { Michigan }\end{array}$ & Retrospective & 381 & ORN \\
\hline $\begin{array}{l}\begin{array}{l}\text { Jeschke et al. } \\
(2001)\end{array} \\
\end{array}$ & 94-00 & $\begin{array}{l}\text { Innsbruck, } \\
\text { Austria }\end{array}$ & Retrospective & 51 & LPN \\
\hline $\begin{array}{|lll|}\begin{array}{l}\text { Kang } \\
(2008)\end{array} & \text { et } & a l . \\
\end{array}$ & $04-06$ & Seoul, Korea & $\begin{array}{l}\text { Prospective, } \\
\text { paired }\end{array}$ & $15-15$ & OPN-LC \\
\hline $\begin{array}{lll}\begin{array}{l}\text { Kaul et } \\
(2007)\end{array} & \text { al. } \\
\end{array}$ & 03-05 & $\begin{array}{l}\text { Detroit, } \\
\text { Michigan }\end{array}$ & & 10 & LPN \\
\hline $\begin{array}{l}\text { Keeley et al. } \\
(2008)\end{array}$ & & $\begin{array}{ll}\text { Bristol } & - \\
\text { Amsterdam } & - \\
\text { Swansea } & - \\
\text { London } & - \\
\text { Vienna - Basel }\end{array}$ & Prospective & 80 & $\mathrm{LC}$ \\
\hline $\begin{array}{lll}\text { Kim et } \\
(2003)\end{array}$ & 98-02 & $\begin{array}{l}\text { Baltimore, } \\
\text { Maryland }\end{array}$ & Prospective & 35 & LRN \\
\hline \begin{tabular}{ll|} 
Kobayashi & et \\
al. $(2008)$ & \\
\end{tabular} & 01-05 & Okayama, Japan & & 20 & LPN \\
\hline $\begin{array}{lll}\begin{array}{l}\text { Lane } \\
(2008)\end{array} & \text { at } \\
\end{array}$ & $99-06$ & Cleveland, Ohio & Retrospective & $30-169$ & LPN-OPN \\
\hline $\begin{array}{l}\begin{array}{l}\text { Lane \& gill } \\
(2007)\end{array} \\
\end{array}$ & $99-01$ & Cleveland, Ohio & $\begin{array}{l}\text { Retrospective } \\
\text { and Prospective }\end{array}$ & 56 & LPN \\
\hline $\begin{array}{l}\text { Lau et al. } \\
(2000)\end{array}$ & $66-99$ & $\begin{array}{l}\text { Mayo clinic, } \\
\text { Rochester, } \\
\text { Minnesota }\end{array}$ & $\begin{array}{l}\text { Retrospective, } \\
\text { paired }\end{array}$ & $164-164$ & OPN-ORN \\
\hline
\end{tabular}




\begin{tabular}{|c|c|c|c|c|c|}
\hline $\begin{array}{l}\text { Lawatsch et al. } \\
(2006)\end{array}$ & 00-04 & $\begin{array}{l}\text { Milwaukee, } \\
\text { Wisconsin }\end{array}$ & Retrospective & 65 & $\mathrm{LC}$ \\
\hline $\begin{array}{l}\text { Lee et al. } \\
(2000)\end{array}$ & $89-97$ & $\begin{array}{l}\text { Memorial } \\
\text { Sloan-Kettering } \\
\text { Cancer Center, } \\
\text { New York } \\
\end{array}$ & $\begin{array}{l}\text { Retrospective } \\
\text { and Prospective }\end{array}$ & $79-183$ & OPN-ORN \\
\hline $\begin{array}{l}\text { Lee et al. } \\
(2003)\end{array}$ & $97-01$ & $\begin{array}{l}\text { Orange, CA - } \\
\text { Bryn Mawr \& } \\
\text { Philadelphie, } \\
\text { Pennsylvanie }\end{array}$ & & 20 & $\mathrm{LC}$ \\
\hline $\begin{array}{l}\text { Leibovich et al. } \\
\text { (2004) }\end{array}$ & $70-20$ & $\begin{array}{l}\text { Mayo clinic, } \\
\text { Rochester, } \\
\text { Minnesota }\end{array}$ & Retrospective & $91-841$ & OPN-ORN \\
\hline Li et al. (2007) & 03-04 & $\begin{array}{l}\text { Kaohsiung, } \\
\text { Taiwan }\end{array}$ & & 6 & LPN \\
\hline $\begin{array}{l}\text { Lin et al. } \\
(2008)\end{array}$ & $99-06$ & Cleveland, Ohio & Retrospective & $14-13$ & LPN-LC \\
\hline $\begin{array}{lll}\text { Littrup } & \text { et } & \text { al. } \\
(2007) & & \\
\end{array}$ & $01-06$ & $\begin{array}{l}\text { Detroit, } \\
\text { Michigan } \\
\end{array}$ & Retrospective & 48 & $\mathrm{PC}$ \\
\hline $\begin{array}{l}\text { Lopez-Costea } \\
(2008)\end{array}$ & $95-03$ & Llobregat, Spain & & 11 & OPN \\
\hline $\begin{array}{l}\text { Makhoul et al. } \\
(2004)\end{array}$ & $95-02$ & Créteil, France & Retrospective & $39-26$ & LRN-ORN \\
\hline $\begin{array}{l}\text { Marszalek et al. } \\
(2008)\end{array}$ & $96-06$ & $\begin{array}{l}\text { Klagenfurt, } \\
\text { Austria }\end{array}$ & Retrospective & $179-131$ & LPN-OPN \\
\hline $\begin{array}{l}\text { McKiernan et } \\
\text { al. (2002a) }\end{array}$ & $89-20$ & $\begin{array}{l}\text { Memorial } \\
\text { Sloan-Kettering } \\
\text { Cancer Center, } \\
\text { New York } \\
\end{array}$ & Retrospective & $117-173$ & OPN-ORN \\
\hline $\begin{array}{l}\text { McKiernan et } \\
\text { al. }(2002 \mathrm{~b})\end{array}$ & $89-02$ & $\begin{array}{l}\text { Memorial } \\
\text { Sloan-Kettering } \\
\text { Cancer Center, } \\
\text { New York } \\
\end{array}$ & Retrospective & 250 & OPN \\
\hline $\begin{array}{lll}\text { Miki et } & \text { al. } \\
(2006) & & \\
\end{array}$ & $01-02$ & Tokyo, Japan & Prospective & 13 & $\mathrm{PC}$ \\
\hline $\begin{array}{l}\text { Mogami et al. } \\
(2002)\end{array}$ & -02 & Chiba, Japan & & 5 & $\mathrm{PC}$ \\
\hline $\begin{array}{lll}\begin{array}{l}\text { Moon et } \\
(2004)\end{array} & & \\
\end{array}$ & $00-02$ & $\begin{array}{l}\text { Madison, } \\
\text { Wisconsin }\end{array}$ & & 16 & $\mathrm{LC}$ \\
\hline $\begin{array}{ll}\text { Mouraviev et } \\
\text { al. (2007) }\end{array}$ & $00-05$ & Durham, NC & Retrospective & $73-71-20$ & LPN-OPN-ORN \\
\hline $\begin{array}{l}\text { Murota et } \\
(2002)\end{array}$ & $99-01$ & Osaka, Japan & & 8 & LPN \\
\hline $\begin{array}{lll}\text { Nadler } & \text { et } & \text { al. } \\
(2003) & & \\
\end{array}$ & $99-02$ & Chicago, Illinois & & 15 & $\mathrm{LC}$ \\
\hline $\begin{array}{lll}\text { Nadler } & \text { et } & \text { al. } \\
(2006) & & \\
\end{array}$ & $01-05$ & Chicago, Illinois & $\begin{array}{l}\text { Prospective, } \\
\text { randomised }\end{array}$ & 33 & LRN \\
\hline $\begin{array}{lll}\begin{array}{l}\text { Nadu } \\
(2007)\end{array} & \text { et } & \text { al. } \\
\end{array}$ & $02-06$ & $\begin{array}{l}\text { Tel Hashomer, } \\
\text { Israel }\end{array}$ & & 140 & LPN \\
\hline $\begin{array}{l}\text { Nakada et } \begin{array}{l}\text { al. } \\
(2001)\end{array} \\
\end{array}$ & $97-00$ & $\begin{array}{l}\text { Madison, } \\
\text { Wisconsin } \\
\end{array}$ & Retrospective & $17-18$ & LRN-ORN \\
\hline $\begin{array}{l}\text { O'Malley et al. } \\
(2006)\end{array}$ & $02-05$ & $\begin{array}{l}\text { New York } \\
\text { University } \\
\text { School of } \\
\text { Medicine, NY } \\
\end{array}$ & $\begin{array}{l}\text { Retrospective, } \\
\text { paired }\end{array}$ & $15-15$ & LPN-LC \\
\hline
\end{tabular}




\begin{tabular}{|c|c|c|c|c|c|}
\hline $\begin{array}{l}\text { Ono et al. } \\
(2001)\end{array}$ & $92-00$ & $\begin{array}{l}\text { Nagoya \& } \\
\text { Komaki, Japan }\end{array}$ & Prospective & $103-46$ & LRN-ORN \\
\hline $\begin{array}{l}\text { Pahernik et al. } \\
(2006)\end{array}$ & $79-04$ & $\begin{array}{l}\text { Mainz, } \\
\text { Germany }\end{array}$ & Retrospective & 504 & OPN \\
\hline $\begin{array}{lll}\text { Patard } & \text { et } & \text { al. } \\
(2007) & & \\
\end{array}$ & $84-05$ & $\begin{array}{l}\text { France - LA, } \\
\text { USA }\end{array}$ & Retrospective & 730 & OPN \\
\hline $\begin{array}{l}\text { Patard et al. } \\
(2004)\end{array}$ & $84-01$ & $\begin{array}{l}\text { California } \\
\text { Italy - France - } \\
\text { Holland }\end{array}$ & Retrospective & $379-1075$ & OPN-ORN \\
\hline $\begin{array}{l}\text { Permpongkosol } \\
\text { et al. (2006a) }\end{array}$ & $96-04$ & $\begin{array}{l}\text { Baltimore, } \\
\text { Maryland - } \\
\text { Long Island, } \\
\text { NY }\end{array}$ & Retrospective & $58-85$ & OPN-LPN \\
\hline $\begin{array}{l}\text { Permpongkosol } \\
\text { et al. }(2006 \mathrm{~b})\end{array}$ & 03-04 & $\begin{array}{l}\text { Baltimore, } \\
\text { Maryland - } \\
\text { Houston, Texas } \\
\text { - Long Island - } \\
\text { Memorial } \\
\text { sloan-Kettering } \\
\text { cancer center, } \\
\text { NY }\end{array}$ & Retrospective & 21 & $\mathrm{PC}$ \\
\hline $\begin{array}{l}\text { Permpongkosol } \\
\text { et al. (2007) }\end{array}$ & $93-05$ & $\begin{array}{l}\text { Baltimore, } \\
\text { Houston, Long } \\
\text { Island } \\
\end{array}$ & Retrospective & $345-549$ & LPN-LRN \\
\hline $\begin{array}{l}\text { Porpiglia et al. } \\
(2005)\end{array}$ & $98-04$ & Turin, Italy & Retrospective & $34-30$ & LPN-OPN \\
\hline $\begin{array}{l}\text { Porpiglia et al. } \\
(2008)\end{array}$ & $01-07$ & Turin, Italy & Retrospective & 90 & LPN \\
\hline $\begin{array}{l}\text { Portis et al. } \\
(2002)\end{array}$ & -96 & $\begin{array}{l}\text { St-Louis, MI - } \\
\text { Saskatoon, CA - } \\
\text { Nagoya, Japan } \\
\end{array}$ & Retrospective & $69-64$ & ORN-LRN \\
\hline $\begin{array}{lll}\begin{array}{l}\text { Pyo } \\
(2008)\end{array} & & a l . \\
\end{array}$ & $02-08$ & NY, NY & Retrospective & 110 & LPN \\
\hline $\begin{array}{lll}\begin{array}{l}\text { Raman } \\
(2008)\end{array} & \text { et } & \text { al. } \\
\end{array}$ & 04-08 & Dallas, Texas & Retrospective & 33 & LRN \\
\hline $\begin{array}{l}\text { Rassweiler et } \\
\text { al. }(2000)\end{array}$ & $94-$ & $\begin{array}{l}\text { Heidelberg, } \\
\text { Germany - } \\
\text { Creteil, France - } \\
\text { Innsbruck et } \\
\text { Klagenfurt, } \\
\text { Austria }\end{array}$ & Prospective & 53 & LPN \\
\hline $\begin{array}{lll}\begin{array}{l}\text { Ray et } \\
(2006)\end{array} & \text { al. } \\
\end{array}$ & 99-05 & Oxford, UK & Retrospective & 100 & OPN \\
\hline $\begin{array}{l}\text { Rodriguez et al. } \\
\text { (2000) }\end{array}$ & -99 & $\begin{array}{l}\text { Baltimore, } \\
\text { Lackland }- \\
\text { Force Air } \\
\text { Texas - Base, Fort } \\
\text { Lauderdale, } \\
\text { Florida - } \\
\text { Atlanta, Georgia }\end{array}$ & & 03-04 & LC-OC \\
\hline $\begin{array}{l}\text { Rogers } \quad \text { et } \quad \text { al. } \\
(2008)\end{array}$ & $07-07$ & Bethesda, MD & & 8 & LPN \\
\hline $\begin{array}{l}\begin{array}{l}\text { Rosales et al. } \\
(2005)\end{array} \\
\end{array}$ & $02-04$ & $\begin{array}{l}\text { Barcelona, } \\
\text { Spain }\end{array}$ & & 14 & LPN \\
\hline
\end{tabular}




\begin{tabular}{|c|c|c|c|c|c|}
\hline $\begin{array}{l}\text { Rukstalis et al. } \\
(2001)\end{array}$ & $96-00$ & $\begin{array}{l}\text { Pittsburgh, } \\
\text { Pennsylvania }\end{array}$ & Retrospective & 29 & $\mathrm{OC}$ \\
\hline $\begin{array}{lll}\begin{array}{l}\text { Saika } \\
(2003)\end{array} & \text { et } & \text { al. } \\
\end{array}$ & $92-02$ & Komaki, Japan & Prospective & $195-68$ & LRN-ORN \\
\hline $\begin{array}{l}\text { Saranchuk et } \\
\text { al. }(2004)\end{array}$ & $89-03$ & $\begin{array}{l}\text { Memorial } \\
\text { Sloan-Kettering, } \\
\text { NY } \\
\end{array}$ & Retrospective & 54 & OPN \\
\hline $\begin{array}{l}\text { Sausville et al. } \\
(2008)\end{array}$ & 03-07 & $\begin{array}{l}\text { Baltimore, } \\
\text { Maryland }\end{array}$ & Retrospective & 02-09 & LC-PC \\
\hline $\begin{array}{lll}\begin{array}{l}\text { Schiff } \\
(2005)\end{array} & \text { et } & \\
\end{array}$ & $00-04$ & NY, NY & $\begin{array}{l}\text { Retrospective } \\
\text { and Prospective }\end{array}$ & $66-59$ & LPN-OPN \\
\hline $\begin{array}{l}\text { Schwartz et al. } \\
\text { (2006) }\end{array}$ & $01-05$ & $\begin{array}{l}\text { Springfield, } \\
\text { Illinois } \\
\text { Calgary, Alberta } \\
\text { - Dallas \& } \\
\text { Arlington, } \\
\text { Texas } \\
\end{array}$ & Retrospective & $70-11$ & LC-OC \\
\hline $\begin{array}{l}\text { Seifman et al. } \\
(2004)\end{array}$ & $98-02$ & $\begin{array}{l}\text { Ann Arbor, } \\
\text { Michigan }\end{array}$ & Retrospective & 40 & LPN \\
\hline $\begin{array}{ll}\text { Sewell } & \& \\
\text { Shingleton } & \\
(2003) & \\
\end{array}$ & & $\begin{array}{l}\text { Jackson, } \\
\text { Mississipi }\end{array}$ & & 103 & $\mathrm{PC}$ \\
\hline $\begin{array}{l}\text { Shekarriz et al. } \\
(2002)\end{array}$ & $91-97$ & $\begin{array}{l}\text { Detroit, } \\
\text { Michigan } \\
\end{array}$ & $\begin{array}{l}\text { Retrospective, } \\
\text { paired }\end{array}$ & $60-60$ & OPN-ORN \\
\hline $\begin{array}{l}\text { Shekarriz et al. } \\
(2004)\end{array}$ & $02-03$ & $\begin{array}{l}\text { Syracuse, New } \\
\text { York }\end{array}$ & Prospective & 17 & LPN \\
\hline $\begin{array}{l}\text { Shingleton \& } \\
\text { Sewell (2001) } \\
\end{array}$ & & $\begin{array}{l}\text { Jackson, } \\
\text { Mississipi } \\
\end{array}$ & & 20 & $\mathrm{PC}$ \\
\hline $\begin{array}{l}\text { Shuford et al. } \\
\text { (2004) }\end{array}$ & $99-01$ & $\begin{array}{l}\text { Nashville, TN - } \\
\text { Orange, CA }\end{array}$ & Retrospective & $33-41$ & LRN-ORN \\
\hline $\begin{array}{l}\text { Silverman et al. } \\
(2005)\end{array}$ & $00-$ & $\begin{array}{l}\text { Boston et } \\
\text { Worcester, MA } \\
\end{array}$ & & 26 & $\mathrm{PC}$ \\
\hline $\begin{array}{ll}\text { Simmons } & \& \\
\text { Gill (2007) } & \\
\end{array}$ & 03-05 & Cleveland, Ohio & Prospective & 200 & LPN \\
\hline $\begin{array}{lll}\text { Simon } & \text { et } & \text { al. } \\
(2004) & & \\
\end{array}$ & $99-03$ & $\begin{array}{l}\text { Scottsdale, } \\
\text { Arizona }\end{array}$ & Retrospective & $23-113$ & LPN-LRN \\
\hline $\begin{array}{lll}\text { Stein } & \text { et } & a l . \\
(2008) & & \\
\end{array}$ & $00-07$ & Durham, NC & Retrospective & 30 & $\mathrm{LC}$ \\
\hline $\begin{array}{l}\text { Steinnerd et al. } \\
(2007)\end{array}$ & $04-06$ & $\begin{array}{l}\text { Saint-Louis, } \\
\text { Missouri } \\
\end{array}$ & Retrospective & 5 & LRN \\
\hline $\begin{array}{l}\text { Stephenson et } \\
\text { al. (2004) }\end{array}$ & $95-02$ & $\begin{array}{l}\text { Memorial } \\
\text { Sloan-Kettering } \\
\text { Cancer Center, } \\
\text { NY }\end{array}$ & $\begin{array}{l}\text { Retrospective } \\
\text { and Prospective }\end{array}$ & $361-688$ & OPN-ORN \\
\hline $\begin{array}{l}\text { Stifelman et al. } \\
\text { (2001) }\end{array}$ & $99-00$ & $\begin{array}{ll}\text { NY, NY } & - \\
\text { Madison, } \\
\text { Wisconsin } \\
\text { Hartford, CN }\end{array}$ & Retrospective & 11 & LPN \\
\hline $\begin{array}{lll}\begin{array}{l}\text { Teber } \\
(2006)\end{array} & \text { et } & \text { al. } \\
\end{array}$ & $99-06$ & $\begin{array}{l}\text { Heilbronn, } \\
\text { Germany }\end{array}$ & Retrospective & 40 & LPN \\
\hline $\begin{array}{lll}\begin{array}{l}\text { Terai } \\
(2004)\end{array} & \text { et } & \text { al. } \\
\end{array}$ & $99-03$ & $\begin{array}{l}\text { Kurashiki \& } \\
\text { Kyoto, Japan }\end{array}$ & & 19 & LPN \\
\hline $\begin{array}{l}\text { Thompson et } \\
\text { al. (2005) }\end{array}$ & $85-01$ & $\begin{array}{l}\text { Memorial } \\
\text { Sloan-Kettering } \\
\text { Cancer Center, } \\
\text { NY }\end{array}$ & Retrospective & 823 & OPN \\
\hline
\end{tabular}




\begin{tabular}{|c|c|c|c|c|}
\hline $\begin{array}{l}\text { Tillett et al. } \\
(2006)\end{array}$ & Atlanta, USA & Retrospective & 58 & $\mathrm{LC}$ \\
\hline $\begin{array}{l}\text { Tornehl et al. } \\
(2004)\end{array}$ & Chapel Hill, NC & & 15 & LPN \\
\hline $\begin{array}{llll}\text { Urena } & \text { et } & \text { al. } & \\
(2004) & & & 02-03\end{array}$ & $\begin{array}{l}\text { New Orleans, } \\
\text { Louisiana }\end{array}$ & Retrospective & 10 & LPN \\
\hline $\begin{array}{l}\text { Van Poppel et } \\
\text { al. (1998) }\end{array}$ & $\begin{array}{l}\text { Leuven, } \\
\text { Belgium }\end{array}$ & Retrospective & 72 & OPN \\
\hline 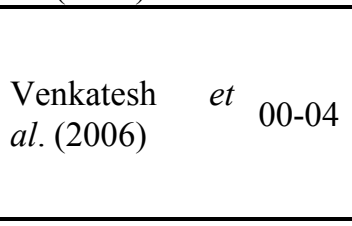 & $\begin{array}{l}\text { St. Louis, } \\
\text { Missouri } \\
\text { Irvine, CA - } \\
\text { Indianapolis, } \\
\text { Indiana } \\
\end{array}$ & Retrospective & 123 & LPN \\
\hline $\begin{array}{l}\text { Verhoest et al. } \\
\text { (2007) }\end{array}$ & Rennes, France & & 5 & LPN \\
\hline $\begin{array}{llll}\text { Weight } & \text { et } & \text { al. } & \\
(2008) & & & 02-06 \\
\end{array}$ & Cleveland, Ohio & Retrospective & 176 & $\mathrm{LC}$ \\
\hline $\begin{array}{llll}\text { Weizer } & \text { et } & \text { al. } & \\
(2008) & & & 03-07 \\
\end{array}$ & $\begin{array}{l}\text { Ann Arbor, } \\
\text { Michigan }\end{array}$ & Retrospective & 174 & LPN \\
\hline $\begin{array}{l}\text { Weld et al. } 00-05 \\
(2007)\end{array}$ & $\begin{array}{ll}\text { St-Louis, } & \\
\text { Missouri } & - \\
\text { Orange, CA - } \\
\text { NY, NY }\end{array}$ & Prospective & 31 & $\mathrm{LC}$ \\
\hline $\begin{array}{l}\text { Weltzien et al. } \\
\text { (2006) }\end{array}$ & $\begin{array}{l}\text { Basel, } \\
\text { Switzerland }\end{array}$ & Prospective & 11 & $\mathrm{LC}$ \\
\hline 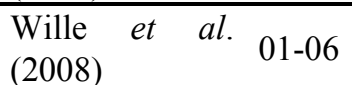 & $\begin{array}{l}\text { Berlin, } \\
\text { Germany }\end{array}$ & Retrospective & 100 & LPN \\
\hline $\begin{array}{llll}\begin{array}{l}\text { Wille } \\
(2004)\end{array} & \text { et } & \text { al. } & \text { 99-03 } \\
\end{array}$ & $\begin{array}{l}\text { Berlin, } \\
\text { Germany }\end{array}$ & Retrospective & 125 & LRN \\
\hline $\begin{array}{l}\text { Wright et al. 03-0 } \\
(2007)\end{array}$ & $\begin{array}{l}\text { Marywood, } \\
\text { Illinois } \\
\text { Baltimore, } \\
\text { Maryland } \\
\end{array}$ & Retrospective & 32 & $\mathrm{LC}$ \\
\hline $\begin{array}{l}\text { Wright } \\
\text { Porter (2005) }\end{array} \quad 98-04$ & $\begin{array}{l}\text { Seattle, } \\
\text { Washington }\end{array}$ & Retrospective & 51 & LPN \\
\hline $\begin{array}{llll}\text { Wyler } & \text { et } & \text { al. } & \\
(2007) & & & \\
\end{array}$ & $\begin{array}{l}\text { Basel, } \\
\text { Switzerland }\end{array}$ & Prospective & 13 & $\mathrm{LC}$ \\
\hline $\begin{array}{l}\text { Yoshikawa } \\
\text { al. }(2004)\end{array}$ et $99-03$ & Nagoya, Japan & Retrospective & 17 & LPN \\
\hline $\begin{array}{llll}\begin{array}{l}\text { Zhang } \\
(2005)\end{array} & \text { et } & \text { al. } & 02-04 \\
\end{array}$ & Wuhan, China & & 21 & LPN \\
\hline $\begin{array}{llll}\begin{array}{l}\text { Zorn } \\
(2007)\end{array} & \text { et } & \text { al. } & \text { 02-06 } \\
\end{array}$ & Chicago, Illinois & Retrospective & $42-66$ & LPN-LRN \\
\hline
\end{tabular}

